\title{
MOTIVASI DAN PRODUKTIVITAS KERJA PEGAWAI \\ SEKRETARIAT DAERAH \\ KABUPATEN PIDIE
}

\section{Zulkifli}

\section{Program Studi Ilmu Administrasi Negara}

\begin{abstract}
ABSTRAK
Motivasi suatu pendorong bagi pegawai untuk mau bekerja dengan giat dan sungguh-sungguh untuk mencapai tujuan yang diinginkan. Produktivitas kerja kemampuan pegawai dan kekuatan organisasi ditentukan oleh sumber daya manusia yang mendukung organisasi ditentukan, bersadasrkan hasil pra penelitian ditemukan motivasi kerja pegawai yang bekerja kurang profesional terkait displin dan pelayanan sehingga mempengaruhi hasil kerja yang kurang maksimal atau produktivitas dalam suatu organisasi. Sekretariat Daerah Kabupaten Pidie adalah salah satu lembaga pemerintah yang menjalani pelayanan publik kepada masyarakat, indikasi yang didapatkan berdasarkan pengamatan adanya ketidakpuasan masyarakat terhadap pelayanan yang diberikan oleh pegawai, maka rumusan maslahnya adalah untuk mengetahui bagaimana motivasi kerja dan bagaimana produktivitas kerja pegawai pada Sekretariat Daerah Kabupaten Pidie.

Tujuan yang hendak dicapai dalam penelitian ini adalah, 1). Untuk mengetahui dan menganalisis motivasi kerja pegawai pada Sekretariat Daerah Kabupaten Pidie. 2). Untuk mengetahui dan menganalisis produktivitas kerja pada Sekretariat Daerah Kabupaten Pidie.

Metode penelitian menggunakan pendekatan kualitatif yaitu prosedur penelitian yang menggunakan data deskriptif yang berupa kata-kata tertulis atau lisan dari perilaku yang diamati untuk memahami fenomena tentang apa yang dialami oleh subjek penelitian, misalnya perilaku, persepsi, motivasi, tindakan, melalui metode wawancara dan pengamatan lapangan, informasi penelitian adalah terdiri dari Bupati Pidie sebagai informan kunci dan sekretaris daerah sebagai informan pengganti dan beberapa kepala bagian dan staf sebagai informan pendukung.

Hasil yang diperoleh bahwa dimensi motivasi fisiologi, motivasi rasa aman, motivasi, motivasi sosial, motivasi pekerjaan dan motivasi aktualisasi diri dapat mendorong motivasi pegawai dalam meningkat kualitas kinerja. Produktivitas kerja pegawai pada Sekretariat Daerah Kabupaten Pidie dengan dimensi pekerjaan, dimensi pegawai, dimensi mengenal dan dimensi sarana dan prasarana merupakan faktor-faktor yang mempengaruhi kerja pegawai untuk meningkatkan kualitas kinerja padaSekretariat Daerah Kabupaten Pidie.

Kesimpulan berdasarkan penelitian ini adalah dimensi motivasi fisiologi, rasa aman, sosial, pekerjaan, dan aktualisasi diri dapat mendorong pegawai dalam meningkatkan kualitas kinerja, sementara dimensi pekerjaan, pegawai, mengenal akan organisasi dan sarana prasarana mempengaruhi produktivitas kerja pegawai dalam meningkatkan kualitas kinerja pad Sekretariat Daerah Kabupaten pidie.
\end{abstract}

Kata Kunci: Motivasi, produktivitas, pegawai dan pelayanan.

\section{LATAR BELAKANG MASALAH}

PembangunanNasional

mengisyaratkan kepada seluruh elemen masyarakat akan pentingnya meningkatkan produktivitas di segala bidang agar tercapainya pemerataan pembangunan. Keberhasilan sebuah produktivitas kerja juga akan dipengaruhi oleh pengelolaan dalam organisasi, baik organisasi yang bersifat formal dan informal. Dengan meningkatkan produktivitas kerja 
diharapkan akan tercapainya tujuan dari organisasi serta dapat meningkatkan barang atau jasa yang dihasilkan dari organisasi tersebut.

Dengan bergulirnya reformasi dan berlakunya Undang-Undang Nomor 9 Tahun 2015 tentang Pemerintahan Daerah bahwa "Pemerintah Pusat untuk menyelenggarakanUrusan

Pemerintahanyang menjadi kewenangan Pemerintah Pusat di Daerah dan wilayah kerja Gubernur dan Bupati/Wali Kota dalam melaksanakanurusan Pemerintah umum di Daerah". Dimanabahwa untuk kesinambungan kepemimpinan di Provinsi, Kabupaten/Kota diperlukan mekanisme peralihan kepemimpinan Daerah di masa Jabatannya yang demokratis untuk dapat menjamin pembangunan dan pelayanan kepada masyarakat dan bahwa ketentuan tugas dan wewenang Dewan Perwakilan Rakyat Daerah Provinsi, Kabupaten/Kota perlu dilakukanpenyesuaian dengan Undang-undang yang mengatur pemilihan Gubernur, Bupati, dan Walikota

Pelayanan Dasar adalah pelayanan publik untuk memenuhi kebutuhan dasar warga Negara, standar Pelayanan Minimal adalah ketentuan mengenai jenis dan mutu Pelayanan dasar yang merupakan urusan Pemerintahan wajib yang berhak diperoleh setiap warga Negara secara minimal.

Motivasi adalah serangkaian sikap dan nilai-nilai yang mempengaruhi individu untuk mencapai hal yang spesifik sesuai dengan tujuan individu.Memotivasi tidak hanya selalu dalam bentuk materi saja misalnya uang, bonus dari atasan, makan dan minum gratis dan lain-lain.Tapi juga dalam bentuk non materi misalnya penghormatan, pujian, promosi, penghargaan, kepercayaan atasan serta keamanan dalam lingkungan kerja.Motivasi Intrinsik yaitu jika kebutuhan seseorang tidak terpenuhi dan terpuaskan pada suatu waktu tertentu. Pemuasan kebutuhan yang lebih dominan akan lebih mendesak dari pada yang lain. Motivasi Ekstrinsik yaitu "motivasi yang diberikan perusahaan dilihat dari hasil kerja karyawan itu sendiri di antaranya pemberian fasilitas penunjang agar karyawan menjadi mudah dalam melakukan pekerjaannya" (Alimuddin, 2015, 796).

Berdasarkan uraian di atas, penulis merasa tertarik untuk meneliti dengan judul "Motivasi Produktivitas Kerja Pegawai Untuk Meningkatkan Pelayanan pada Sekretariat Daerah Kabupaten Pidie".

\section{Identifikasi Masalah}

Berdasarkan latar belakang di atas, maka dapat diuraikan beberapa identifikasi dan rumusan masalah adalah:

a Motivasi kerja pegawai melalui dimensi fisiologi, rasa aman, sosial, penghargaan dan aktulisasi diri pada Sekretariat Daerah Kabupaten Pidie

b Produktivitas kerja pegawai melalui dimensi pekerjaan, pegawai sendiri, manajerial dan peralatan yang digunakan (sarana dan prasarana) pada Sekretariat Daerah Kabupaten Pidie.

\section{Rumusan Masalah}

Berdasarkan latar belakang di atas, maka dapat diuraikan beberapa rumusan masalah adalah:

a Bagaimana motivasi kerja pegawai pada Sekretariat Daerah Kabupaten Pidie.

b Bagaimana produktivitas kerja pada Sekretariat Daerah Kabupaten Pidie.

\section{Tujuan Penelitian}

Setiap usaha atau kegiatan tentu mempunyai tujuan yang hendak dicapai dalam penelitian ini adalah sebagai berikut:

1. Untuk mengetahui dan menganalisis motivasi kerja pegawai pada Sekretariat Daerah Kabupaten Pidie Tahun 2017.

2. Untuk mengetahui dan menganalisis produktivitas kerja pada Sekretariat Daerah Kabupaten Pidie Tahun 2017.

\section{Kegunaan Penelitian}

1. Kegunaan Teoritis 
a Memberikan kajian teori tentang motivasi dalam meningkatkan produktivitas pegawai padainstansi pemerintahan dan membandingkannya dengan teori-teori berkaitan dengan motivasi dan produktivitas kerja pegawai untuk meningkatkan pelayanan pada Sekretariat Daerah Kabupaten Pidie.

b Diharapkan dapat menjadi referensi atau masukan bagi perkembangan disiplin ilmu administrasi dalam rangka meningkatkan produktivitas pegawai melalui motivasi dan produktivitas kerja pegawai untuk meningkatkan pelayanan pada Sekretariat Daerah Kabupaten Pidie.

2. Kegunaan Praktis

a Untuk memberikan informasi kepada instansi pemerintah maupun pihak-pihak lain yang membutuhkannya motivasi dan produktivitas kerja pegawai untuk meningkatkan pelayanan pada Sekretariat Daerah Kabupaten Pidie.

b Bagi penulis khususnya, penelitian ini bermanfaat untuk mengembangkan kemampuan penulis menulis karya ilmiah, terutama dalam menganalisa permasalahan yang terjadi di masyarakat yang ada kaitannya dengan ilmu yang didapat di dalam perkuliahan motivasi dan produktivitas kerja pegawai untuk meningkatkan pelayanan pada Sekretariat Daerah Kabupaten Pidie.

\section{METODE PENELITIAN \\ Pendekatan Penelitian}

Jenis penelitian ini adalah menggunakan pendekatan kualitatif.Menurut Bodgan dan Taylor dalam Moleong (2013: 4) "penelitian kualitatif adalah prosedur penelitian yang menggunakan data deskriptif yang berupa kata-kata tertulis atau lisan dari perilaku yang diamati". Menurut mereka, pendekatan ini diarahkan pada luar dan individu tersebut secara holistic (utuh) "prosedur penelitian yang menghasilkan data deskriptif berupa kata-kata tertulis atau lisan dari orang-orang dan perilaku yang dapat diamati".Senada dengan hal tersebut,
Denzim dan Lincoln (1987) dalam Moleong (2013: 5) mengemukakan penelitian kualitatif adalah "penelitian yang menggunakan latar alamiah, dengan maksud menafsirkan fenomena yang terjadi dan dilakukan dengan jalan melibatkan berbagai metode yang ada". Masih senada dengan di atas, Moleong (2013 : 6) menyimpulkan :

Penelitian kualitatif adalah penelitian yang bermaksud untuk memahami fenomena tentang apa yang dialami oleh subjek penelitian, misalnya perilaku, persepsi, motivasi, tindakan, dll, secara holistic, dan dengan cara deskripsi dalam bentuk kata-kata dan bahasa, pada suatu konteks yang alamiah dan dengan memanfaatkan berbagai metode alamiah.

\section{Fokus Penelitian}

Fokus penelitian sebenarnya sangat diperlukan dalam suatu penelitian agar mampu menganalisis arah maupun sasaran si peneliti yang tidak diperlukan, namun tetap memfokuskan pada:

1. Motivasi kerja pegawai pada Sekretariat Daerah Kabupaten Pidie dengan dimensi dan individu:

\begin{tabular}{|c|c|c|}
\hline No & Dimensi & Indikator \\
\hline 1. & $\begin{array}{l}\text { Motivasi } \\
\text { Fiosiologi }\end{array}$ & $\begin{array}{l}\text { a. Nutrisi (Makanan } \\
\text { dan Minum) } \\
\text { b. Waktu Kerja } \\
\text { (istirahat) } \\
\text { c. Hiburan }\end{array}$ \\
\hline 2. & $\begin{array}{l}\text { Motivasi } \\
\text { Rasa Aman }\end{array}$ & $\begin{array}{ll}\text { a. } & \text { Rasa Aman Fisik } \\
\text { b. Stabilitas } \\
\text { c. Perlindungan dan } \\
\text { Kebebasan }\end{array}$ \\
\hline 3. & $\begin{array}{l}\text { Motivasi } \\
\text { Sosial }\end{array}$ & $\begin{array}{l}\text { a. Hubungan antar } \\
\text { pegawai } \\
\text { b. Lingkungan Kerja } \\
\text { c. Relasi dalam } \\
\text { Masyarakat }\end{array}$ \\
\hline 4. & $\begin{array}{l}\text { Motivasi } \\
\text { Penghargaan }\end{array}$ & $\begin{array}{l}\text { a. Dipuji } \\
\text { b. Dihargai } \\
\text { c. Prestasi } \\
\end{array}$ \\
\hline 5. & $\begin{array}{l}\text { Motivasi } \\
\text { Aktualisasi }\end{array}$ & $\begin{array}{ll}\text { a. Pelatihan khusus } \\
\text { b. Gaji dan } \\
\text { tunjangan }\end{array}$ \\
\hline
\end{tabular}




\begin{tabular}{|c|c|}
\hline diri & $\begin{array}{l}\text { c. Realisasi } \\
\text { Pekerjaan }\end{array}$ \\
\hline
\end{tabular}

2. Produktivitas kerja pada Sekretariat Daerah Kabupaten Pidie dengan dimensi dan indikator :

\begin{tabular}{|c|c|c|}
\hline No & Dimensi & Indikator \\
\hline 1. & Pekerjaan & $\begin{array}{ll}\text { a. } & \text { Jenis Pekerjaan } \\
\text { b. Lama Bekerja } \\
\text { c. Resiko Pegawai }\end{array}$ \\
\hline 2. & $\begin{array}{l}\text { Pegawai } \\
\text { Sendiri }\end{array}$ & $\begin{array}{ll}\text { a. } & \text { Gaji Pegawai } \\
\text { b. Kebutuhan Pegawai } \\
\text { c. Lingkungan Kerja }\end{array}$ \\
\hline 3. & Manajerial & $\begin{array}{ll}\text { a. Kepemimpinan } \\
\text { b. Struktur Organisasi } \\
\text { c. Kewenangan }\end{array}$ \\
\hline 4. & $\begin{array}{l}\text { Peralatan } \\
\text { yang } \\
\text { digunakan } \\
\text { (sarana } \\
\text { dan } \\
\text { Prasarana) }\end{array}$ & $\begin{array}{ll}\text { a. Mesin/ Manual/ } & \text { Aoutomatis } \\
\text { b. Teknelogi } \\
\text { c. }\end{array}$ \\
\hline
\end{tabular}

\section{Lokasi Penelitian}

Penelitian ini bertujuan untuk mendapat gambaran dan informasi yang lebih jelas, lengkap, serta memungkinkan dan mudah bagi peneliti untuk melakukan penelitian observasi, wawancara dan dokumentasi.

Lokasi penelitian ditetapkan di lingkungan Sekretariat Daerah Kabupaten Pidie dengan responden pegawai kantor. Alasan penulis lokasi ini karena ingin mengetahui motivasi dan produktivitas kerja pegawai pada Sekretariat Daerah Pemerintahan Kabupaten Pidie.

\section{Jenis dan Sumber Data}

\section{Data Primer}

Data mentah yang didapatkan langsung dari penelitian ini meliputi data yang didapatkan dari hasil penelitiantentang motivasi dan produktivitas kerja pegawai pada Sekretariat Daerah Kabupaten Pidie.

2. Data Sekunder

Data yang didapatkan berdasarkan dari perpustakaan, fokus ini dilakukan agar dapat menemukan dokumen-dokumen sebagai referensi pelengkap penelitian.

\section{Informan Penelitian}

Informan dalam penelitian ini adalah pegawai yang bekerja di Sekretariat Daerah Kantor Bupati Pidie menggunakan penelitian kualitatif, hal yang menjadi bahan pertimbangan utama dalam pengumpulan data adalah pemilihan informan.Dalam penelitian kualitatif tidak digunakan istilah populasi.

Kualitatif tidak dimaksudkan untuk membatu generalisasi dari hasil penelitiannya.Oleh karenaitu, pada penelitian kualitatif tidak dikenal adanya populasi dan sampel. Subjek penelitian yang telah tercermin dalam fokus penelitian ditentukan secara sengaja. Subjek penelitian ini menjadi informan yang akan memberikan berbagai informasi yang diperlukan selama proses penelitian, informan penelitian ini meliputi beberapa macam seperti :

1. Informan kunci, yaitu mereka yang mengetahui dan memiliki berbagai informasi pokok yang diperlukan dalam penelitian;

2. Informan utama, yaitu mereka yang terlibat langsung dalam interaksi sosial yang diteliti;

3. Informan tambahan, yaitu mereka yang dapat memberikan informasi walaupun tidak langsung terlibat dalam interaksi sosial yang diteliti (Suyanto, 2005 : 171).

Menurut Usman (2009 : 82) "dalam penelitian kualitatif tidak dikenal istilah populasi, tetapi samplingyang merupakan pilihan peneliti sendiri dan yang ditentukan peneliti sendiri secara purposive yang disesuaikan dengan tujuan penelitiannya, sampling tersebut dijadikan responden yang relevan untuk mendapatkan data".

Berdasarkan subjek penelitian seperti yang telah disebutkan bahwa pemilihan informan pertama merupakan hal yang sangat utama sehingga harus dilakukan secara cermat, karena penelitian ini mengkaji tentang motivasi produktivitas 
kerja pegawai maka peneliti memutuskan informan pertama atau informan kunci yang paling tepat adalah Bupati Pidie dan selanjutnya Setda Pidie sebagai informan utama yang seterusnya adalah ketua bagian pelayanan masyarakat beserta staf atau pegawai yang terlibat langsung untuk memberikan pelayanan kepada masyarakat.

\section{HASIL}

1. Produktivitas Kerja Pegawai pada Sekretariat Daerah Kabupaten Pidie dengan Dimensi-dimensi

a Dimensi Pekerjaan

Upaya peningkatan produktivitas kerja salah satunya implementasi ialah bahwa seluruh komponen harus melakukan perbaikan secara terus menerus. Pandangan ini bukan hanya merupakan suatu kiat tetapi salah satu etos kerja yang penting.Pekerjaan paling tidak memiliki lima dimensi (Simamora, 2014: 106) yang berinteraksi satu sama lain dan menentukan tingkat produktivitas dan kepuasan yang di peroleh atas pekerjaan. Maka indikatornya adalah sebagai berikut :

1) Jenis Pekerjaan

Pegawai Negeri adalah setiap warga negara Republik Indonesia yang telah memenuhi syarat yang ditentukan, diangkat oleh pejabat yang berwenang dan diserahi tugas dalam suatu jabatan negeri, atau diserahi tugas negara lainnya, dan digaji berdasarkan peraturan-perundang-undangan yang berlaku.Pegawai Negeri berkedudukan sebagai unsur aparatur negara yang bertugas untuk memberikan pelayanan kepada masyarakat secara professional, jujur, adil, dan merata dalam penyelenggaraan tugas negara, pemerintah, dan pembangunan.Pegawai Negeri harus netral dari pengaruh semua golongan dan partai politik serta tidak diskriminatif dalam memberikan pelayanan kepada masyarakat.

2) Lama Bekerja

Adapun pengalaman
didefinisikan sebagai sesuatu atau
kemampuan yang dimiliki oleh para
karyawan dalam menjalankan tugas-tugas
yang dibebankan kepadanya. Dengan
pengalaman yang cukup panjang dan cukup

banyak maka diharapkan mereka akan mempunyai kemampuan yang lebih besar daripada yang tanpa pengalaman.

Ukuran tentang lama waktu atau masa kerja yang telah ditempuh seseorang dapat memahami tugas-tugas suatu pekerjaan dan telahmelaksanakan dengan baik.Pengetahuan merujuk pada konsep, prinsip, prosedur, kebijakan atau informasi lain yang dibutuhkan oleh pegawai. Pengetahuan jugamencakup kemampuan untuk memahami dan menerapkan informasi pada tanggung jawab pekerjaan. Sedangkan keterampilan merujuk pada kemampuan fisik yang dibutuhkan untuk mencapai atau menjalankan suatu tugas atau pekerjaan.

\section{3) Resiko Pekerjaan}

Risiko yang ditimbulkan pegawai perlu dikelola agar tidak menimbulkan kerugian, baik finansial maupun reputasi, hal ini dilakukan untuk mengurangi resiko merugikan brand nama perusahaan. Manajemen risiko merupakan salah satu cara untuk mengatasi hal itu. Karena manajemen risiko merupakan proses pengukuran atau penilaian serta memerlukan seni untuk mengembangkan strategi pengelolaannya, misalnya risiko itu dipindahkan kepada pihak lain, mengurangi efek negatif dari risiko, dan lain-lain. Pada model pendekatan tradisional, risiko yang ditimbulkan oleh SDM hanya berkisar pada kematian, tuntutan hukum, dan upah). Agar tidak menimbulkan risiko, maka SDM perlu dikelola secara profesional, yaitu dengan memperhatikan kaidah-kaidah yang ada dalam manajemen SDM.

\section{Pembahasan}

1. Motivasi Kerja Pegawai Pelayanan Pada Sekretariat Daerah Kabupaten Pidie.

a Motivasi Fisiologi

Kebutuhan motivasi fisiologi merupakan dimensi penting dalam pengukuran tingkat motivasi pegawai dengan indikator nutrisi (makan dan minum), waktu kerja dan tempat tinggal pegawai dalam meningkatkan hasil kerja yang lebih efektif bahwa kebutuhan dasar. 
Kebutuhan untuk mempertahankan hidup disebut juga dengankebutuhan psikologis (physiological needs), yaitu kebutuhanuntuk mempertahankan hidup dari kematian. Kebutuhan ini merupakan tingkat paling dasar yang diperkenalkan oleh Maslow. Kebutuhan paling dasar ini berupa kebutuhan akan makan, minum, perumahan, pakaian, yang harus dipenuhi oleh seseorang dalam upayanya untuk mempertahankan diri dari kelaparan, kehausan, kedinginan, kepanasan dan sebagainya (Bangun, 2014: 211)

Kebutuhan fisiologis berbeda dari kebutuhan-kebutuhan lain dalam dua hal.Pertama, kebutuhan fisiologis adalah satu-satunya kebutuhan yang bisa terpuaskan sepenuhnya atau minimal bisa diatasi.Manusia dapat merasakan cukup dalam aktivitas makan sehingga pada titik ini, daya penggerak untuk makan akan hilang.Bagi seseorang yang baru saja menyelesaikan sebuah santapan besar, dan kemudian membayangkan sebuah makanan lagi sudah cukup untuk membuatnya mual.Kedua, yang khas dalam kebutuhan fisiologis adalah hakikat pengulangannya.Setelah manusia makan, mereka akhirnya akan menjadi lapar lagi dan akan terus menerus mencari makanan dan air lagi.Sementara kebutuhan di tingkatan yang lebih tinggi tidak terus menerus muncul.Sebagai contoh, seseorang yang minimal terpenuhi sebagian kebutuhan mereka untuk dicintai dan dihargai akan tetap merasa yakin bahwa mereka dapat mempertahankan pemenuhan terhadap kebutuhan tersebut tanpa harus mencaricarinya lagi. (Bangun, 2014: 212)

Gambaran hasil berdasarkan pembahasan tersebut maka dirumuskan Temuan 1 (satu) sebagai berikut:

Temuan 1:Motivasi fisiologi merupakan kebutuhan pokok bagi pegawai pada Sekretariat Daerah Kabupaten

Berdasarkan pembahasan tersebut di atas maka dirumuskan Temuan 2 (dua) sebagai berikut.

Temuan 2:Kebutuhan dasar atau motivasi fisiologi pegawai Sekretariat Daerah
Kabupaten Pidie dengan kategori baik, dimana status kebutuhan dasar dan jaminan kesehatan sudah terpenuhi.

Berdasarkan temuan 1 (satu) dan 2 (dua) tersebut di atas maka

Proposisi Minor 1: Kebutuhan dasar pegawai di Sekretariat Daerah Kabupaten Pidie dapat mendorong terciptanya motivasi fisiologi dengan baik.

b Motivasi Rasa Amandirumuskan Proposisi Mayor 1 (satu) sebagai berikut:

Dalam mengidentifikasi motivasi rasa aman dengan indikator rasa aman fisi, stabilitas dan perlindungan dan kebebasan pegawai merupakan halpenting yang perlu diperhatikan dalam rangka mencapai kualitas kinerja di lingkungan Sekretariat Daerah kabupaten Pidie.

\section{Kesimpulan}

Menganalisis berbagai data hasil penelitian penerapan dalam berbagai penjabaran motivasi produktivitas kerja pegawai dalam meningkatkan pelayanan pada Sekretariat Daerah KabupatenPidie. Adapun kesimpulan sebagai berikut:

1. Motivasikerja pegawai pada Sekretariat Daerah KabupatenPidie.

Berdasarkan hasil penelitian di lapangan dapat disimpulkan bahwa indikator yangsangat mempengaruhi adalah dimensi motivasi filosofis pegawai dengan berbagai indikator dasar sudah baik sehingga hal sudah memeotivasi pegawai untuk berkerja secara optimal dan profesional untuk kebutuhan suatu oragnisasi.

Adapun dimensi lain adalah motivasi rasa aman dengan berbagai indikator kebutuhan pegawai dalam meningkatkan kinerja sangat dipengaruhi olehkeadaaan tempat kerja, adanya keselamatan yang dapat terlindungi dari ancaman terjadi, sehingga tingkan perlindungannya mendapatkan jaminan dan hal akan mendorong pegawai untuk bekerja untuk kebutuhan organisasi dan kebutuhan lainnya. 
Substansi kebutuhan motivasi sosial pegawai pada Sekretariat Daerah Kabupaten Pidie sangat baik dengan pengukuran indikator hubungan antar pegawai, lingkungan kerja dan sikap sesama dalam melakukan pekerja sesuai prosedur yang telah ditentukan.

\section{DAFTAR PUSTAKA}

Alimuddin. (2015). Pengaruh Motivasi Terhadap

ProduktivitasKerjaKaryawaneJourna IIlmuAdministrasiBisnis, 2015, 3 (4): 795-805 ISSN 2355-5408, ejournal.adbisnis.fisip-unmul.ac.id
Bangun, (2014). Manajemen Sumber Daya Manusia, Jakarta :Erlangga.

Moleong, LexyJ.1 (2010).Metodologi Penelitian Kualitatif, Bandung: PT. Remaja Rosdakarya.

Simamora, Henry. (2014). Tata Kerja dan Produktivitas Kerja.Bandung: Mandar Maju.

Undang-Undang Republik Indonesia Nomor 9 Tahun 2015 tentang Pemerintah Daerah. 